\title{
Analysis of Factors Influencing Household Human Capital Investment Behavior in Conflict Zones: A Case Study of District Swat
}

\author{
Amjad Amin, Danish Alam, Nadeem Iqbal \\ ${ }^{a}$ Assistant Professor at the Department of Economics University of Peshawar, Pakistan \\ Email: amjadamin@uop.edu.pk \\ ${ }^{\mathrm{b}}$ Lecturer at the Department of Economics University of Peshawar, Pakistan \\ Email: danish_alam@uop.edu.pk \\ ${ }^{c}$ Assistant Professor at the Department of Economics University of Peshawar, Pakistan \\ Email: bnadeemiqbal@uop.edu.pk
}

\begin{tabular}{|c|c|}
\hline ARTICLE DETAILS & \multirow{10}{*}{$\begin{array}{l}\text { ABSTRACT } \\
\text { Development of human capital, as part of public policy is critical for } \\
\text { sustainable socio-economic development of a country. This study } \\
\text { analyzed the factors that influenced the household behavior of spending } \\
\text { on human resources in terrorism affected region of district Swat. The } \\
\text { uniqueness of the current study is to study human capital behavior in } \\
\text { the study area. The econometric technique (OLS) was applied to analyze } \\
\text { the data. The study found that there are direct and indirect relationship } \\
\text { exists among the targeted variables. It was found that health and } \\
\text { education status is negatively affected by the incidence of terrorism. The } \\
\text { education system drastically affected and the enrolment rate at the } \\
\text { primary, secondary and post-secondary levels have exceptionally } \\
\text { declined because of the aftermath of terrorism episode between } 2002 \\
\text { and 2016. Health, education facilities and infrastructure are } \\
\text { deteriorating posing a threat to long term development. The effective } \\
\text { policies of the Government (investment in human capital) and } \\
\text { eradicating terrorism (military actions) is a demanding subject of } \\
\text { matter for the sake of development in the area. }\end{array}$} \\
\hline & \\
\hline & \\
\hline & \\
\hline & \\
\hline Human & \\
\hline Conflic & \\
\hline JEL & \\
\hline E24, & \\
\hline & \\
\hline
\end{tabular}

(C) 2020 The authors. Published by SPCRD Global Publishing. This is an open access article under the Creative Commons Attribution-

NonCommercial 4.0

Corresponding author's email address: amjadamin@uop.edu.pk

\section{Introduction}

Physical resource are the major components of human resources, to making use of natural resources, construct socioeconomic organizations and make strengthen the economic growth and development of nation (Roomer, 1998.) Numerous quantitative researches have been undertaken in western countries on economic development, the studies evidenced that the development in the west did not come from the physical resources but it happened due to the provision of human resources. (Lucas, 1976; Schultz, 1961). In developed countries the growth is a dynamic source of human capital. 


\section{Review of Economics and Development Studies, Vol. 6 (4) 2020881 - 891}

Qaiser, (2000) divides human capital investment into public investment and household investment in health and education related activities. In Pakistan some of the researchers focused on quantitative based research on the same theme, specifically Khyber Pakhtunkhwa has badly influenced due to the terrorist attack. Studies (like Lucas 1976, and Schultz 1961) went through quantitative based research and tried to examine the bivariate association between spending on human resources and household income. Terrorism has severely affected the educational environment of Khyber Pakhtunkhwa (KP) province of Pakistan. Pakistan is a developing country, where KP suffered a lot due to terrorism (Khan, 2019).

Human capital in education and health brings structural change in the economy. This structural change in the economy brings economic development in coming years. Terrorists have targeted the schools and hospitals to affect the path of social development and hence economic development and to reduce the poverty. Phelps \& Nelson (1966) explored that the advancement of a country based to investing on human capital and developed technology, which merely happened when a country has its own human capital stock. Siddiqui et al (1995) examined the key factors which have influential effect on health related goods and services and found that the development is directly affected by to spending on education and health. Qaisar, A (2000) did a comparative study on behavioral tendency toward investment of human capital, the two countries Pakistan and India. Mimoun, B. et al (2008) studied about the limited human capital stock and employed the Optimal Control Principle. The study revealed that the short-run and long-run growth of a country will groom up along with increase in higher education. Yamauchi, et al (2009) focused the impact of natural disaster on human capital stock for the countries Bangladesh, Ethiopian and Malawi and used panel data. Yang, C. H. et al (2010) applied panel data for the period of 2005-2007 and the study examined the various firms and it also explored the production capacity of the China's electronic industry by Research \& and Development (R\&D) and human resources. The growth and development of an economy significantly depends upon the quality of its human capital -- the knowledge and skills -- of their workers (Neilson, 2020).

The objective the research is to gather empirical evidence on the determinants of human resources investment decision made by the households, based on their respective religious status, in the terrorism affected areas. The study comprises different socio-economic factors, such as family's religious status and society. To investigate the human behavior to spending on human resources in Swat district, which is affected by the terrorists, a particular framework is followed. A key implication of my research is the importance of it being a base research that could provide an insight to future researchers interested to work in this area.

\section{Research Method}

To achieve for the sat objective the methodology is followed as;

\subsection{Sampling and Data Collection}

In this study, three union councils have been taken in Swat district. The names of the union council are Kaanju, Nawaan Kalay and Charbagh Cham. The selected union councils were severely affected by the terrorist attack and so these three have taken as sample for the study. From each of the union councils 50 sample have been taken and total sample taken as 150 . The systematic approach is employed form the sampling technique (Roomer, 1986; Qaiser, 2000). Secondary data is collected from District health and education departments of Swat for the period 2005 to 2014 . The justification of selecting this period is that terrorism was at peak level in this time period in the region. 


\subsection{Analytical Technique}

\subsubsection{Determinants of household human capital investment behaviour}

The multivariate regression method has been employed in the research. Like (Behrman and Schneder, 1993; Siddique, 1995 have analyzed the household behavior concerning to spending on human development and used the same technique. This study has applied some different variables based on the structure and social values of the area (Family structure, and religion). Behrman and Schneider (1993) have done a deep-seated analysis and took the quality of good and services, household income, price, education background and return for human investment. The same technique has been used by the researcher as we used here and the allocated country is Pakistan. Siddiqui (1995) have analyzed the socioeconomic variables like income, education and urbanization.

\section{Theoretical Model}

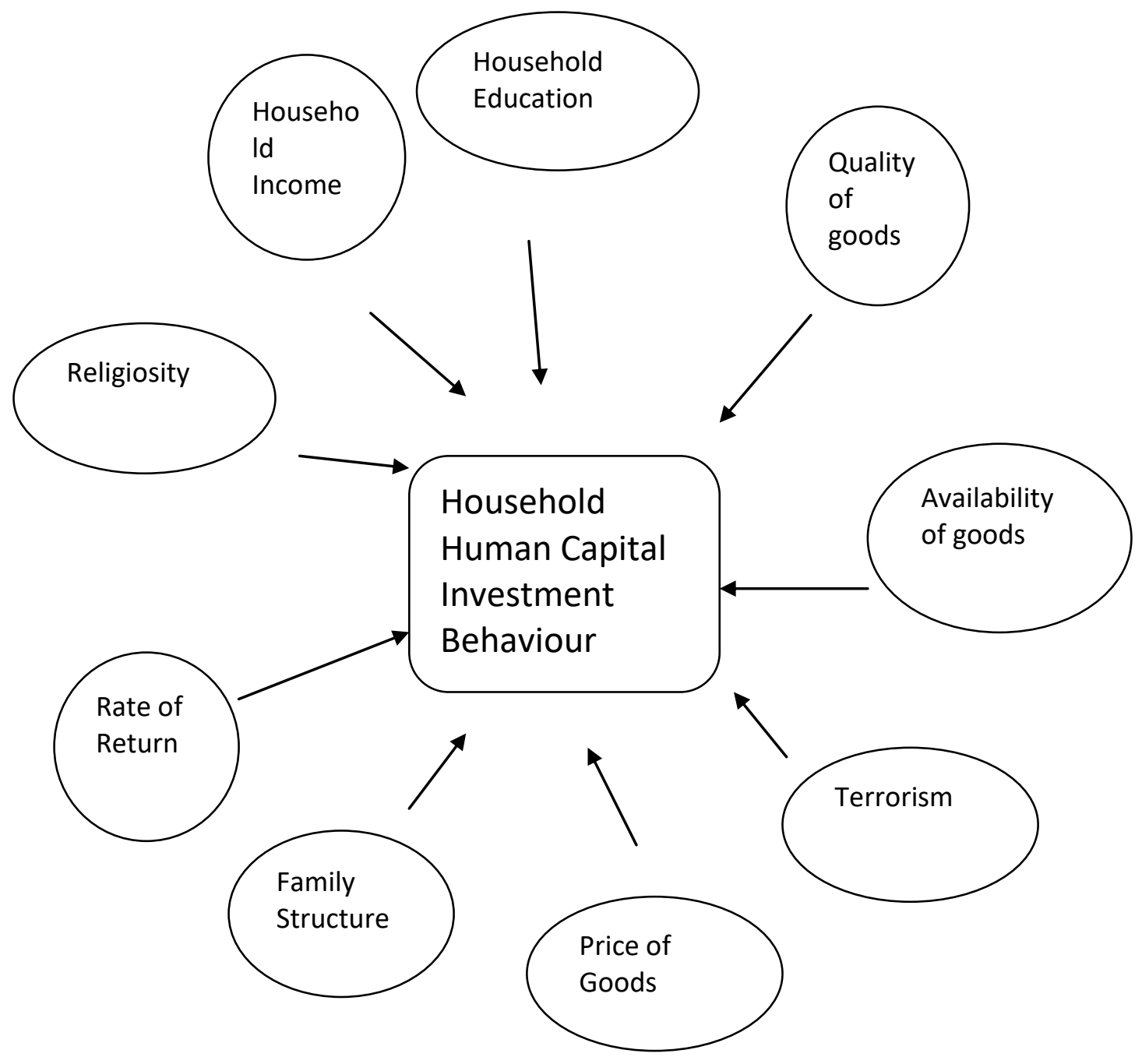

Fig 1: Theoretical Model

Thus the model is constructed Mathematically as;

$$
\begin{aligned}
& H C I=\beta 0+\beta 1 Y+\beta 2 D F B+\beta 3 P+\beta 4 D Q+\beta 5 D R R+\beta 6 D E A+\beta 7 R+\beta 8 F S+
\end{aligned}
$$

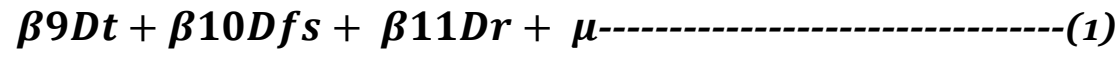


Where,

$\mathrm{HCI}=$ investment on human capital by household, the total gross expenditure of household is used as proxy variable for HCI.

$\mathrm{Y}=$ The income of the family.

DFB =Dummy variable for the education level of the family. It will give the values $\left\{\begin{array}{c}=1 \text {, if eductaed } \\ =0, \text { if otherwise }\end{array}\right.$ $\mathrm{P}=$ Used as Human Capital Investment's prices of goods and services.

$\mathrm{DQ}=$ Used as dummy variable for quality. It has given value $\left\{\begin{array}{c}=1, \text { if high quality } \\ =0, \text { if otherwise }\end{array}\right.$

$\mathrm{DRR}=$ Dummy used for Return on investment. It has values as $\left\{\begin{array}{c}=1 \text {, if high return } \\ =0 \text {, } \text { otherwise }\end{array}\right.$

$\mathrm{DEA}=$ As a dummy variable showing goods and services are available. Holding the values $\{=1$, if available

$\{=0$, otherwise

$\mathrm{R}=$ The religion and society. The value holding 1 if family follow the religion and social values.

FS = Status of family. If the family structure is nuclear the weightage is given 1 , if jointly reside then weightage is 0 .

$\mathrm{D}_{\mathrm{fc}}=$ Used as dummy variable for family structure. The value 1 is given for the joint family structure and o for otherwise.

$\mathrm{D}_{\mathrm{t}}=$ Dummy used incidence of terrorism. If value is 1 means conflict and if o means no conflict $\mathrm{D}_{\mathrm{t}}=$ Dummy used for religion. The value 1 means highly religious and o not

$$
\begin{gathered}
\beta 0=\text { the } Y-\text { intercept } \\
\mu=\text { error term }
\end{gathered}
$$

\section{Results and Discussion}

The pre and post terrorism is explained in the following figure and it indicates the health and education status of the affected region.

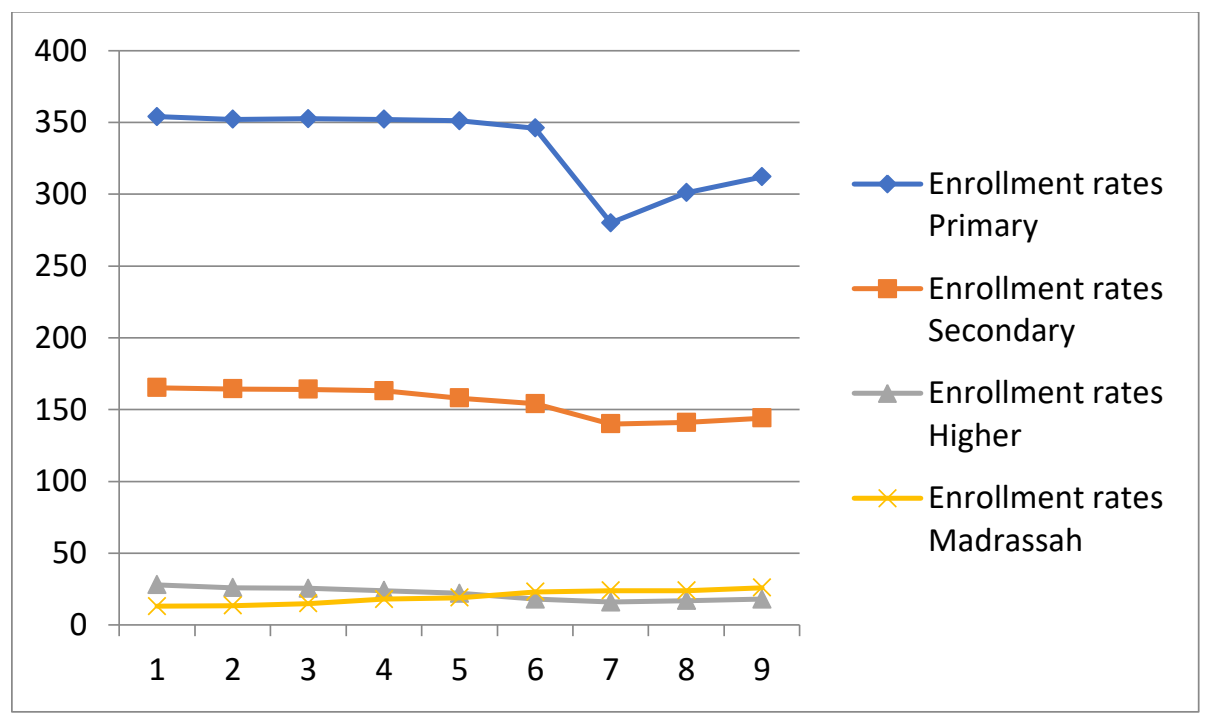

Fig. 1

(Source: Health\&Education Department, Swat) (On X-axis is year from 2005 to 2014 and on Y-axis is enrollment rates in thousand) 
Due to the continual terrorist attack the enrollment rates (primary, secondary and higher) have decreased as the figure portrayed. The inhabitants of the study area are chronically religious loving people. The tendency of enrollment moved towards Madrassas instead of government schools and colleges. The religious preachers played leading role in this movement. As the diagram confirmed that the strength of the movement of enrollment rates towards Madrassas tends to rise during the period.

\subsection{Government spending on health \& education services in Swat}

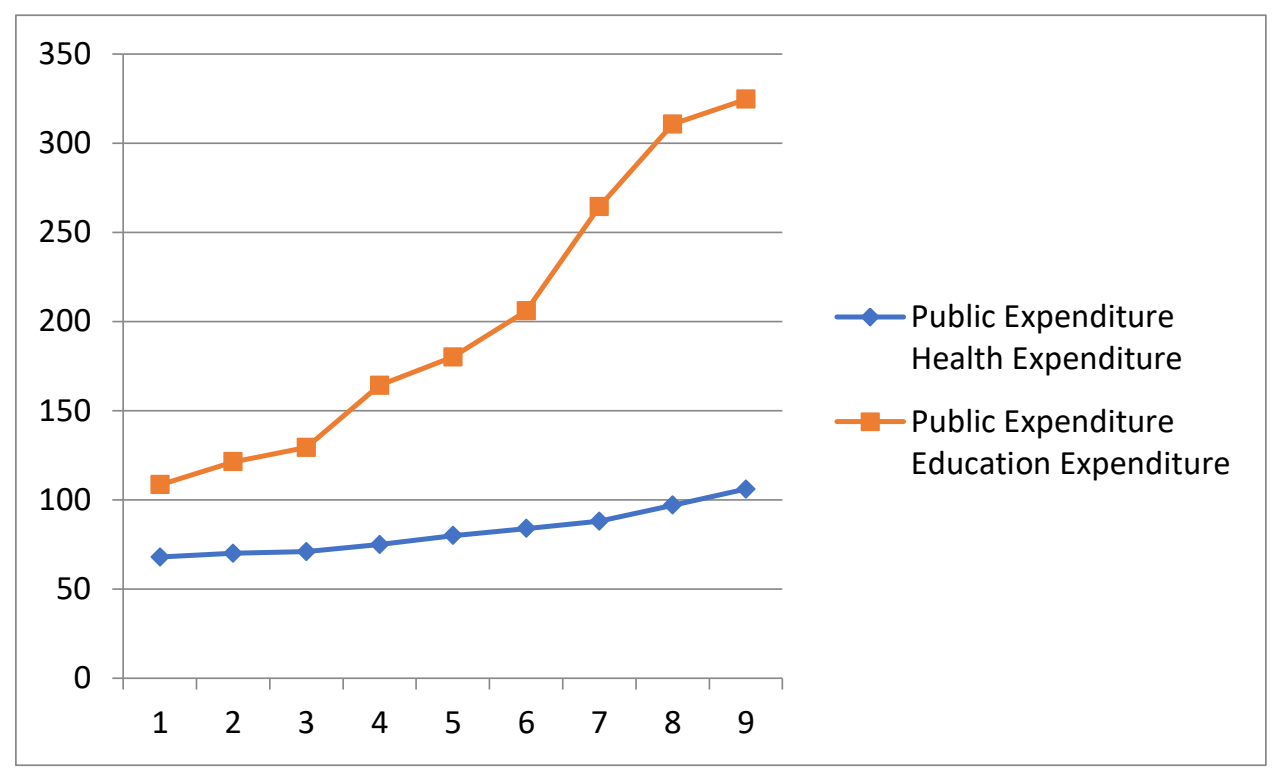

Fig. 2

(Source: Health\&Education Department, Swat) (On X-axis is year from 2005 to 2014 and on $\mathrm{Y}$-axis is enrollment rates in Million)

The government's institutions (schools, colleges and hospitals) badly wrecked due to the terrorist attack and to rehabilitation of the infrastructure the government spent a major part of budget. Due to damages and destruction of the educational building by the terror the government has to re-build the schools and colleges and it increased the spending of the government.

\subsection{Family size and Dependency Ratio}

The household size is the number of family members to reside in a home. The information about the household size and dependency ratio is given in Table 1.

Table 1: Family size \& dependency-ratio

\begin{tabular}{|c|c|c|c|c|c|c|}
\hline 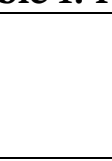 & 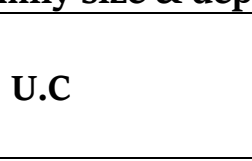 & $\mathbf{n}$ & $\begin{array}{l}\text { Average } \\
\text { Family Size }\end{array}$ & $\begin{array}{l}\text { Overall } \\
\text { family size }\end{array}$ & $\begin{array}{l}\text { Average } \\
\text { Dependency- } \\
\text { Ratio } \\
\end{array}$ & $\begin{array}{l}\text { Overall } \\
\text { \%age }\end{array}$ \\
\hline \multirow{3}{*}{ Swat } & UC-Kaanju & 50 & 5.5 & \multirow{3}{*}{$5 \cdot 4$} & 0.74 & \multirow{3}{*}{0.76} \\
\hline & $\begin{array}{l}\text { UC-Charbagh } \\
\text { Cham }\end{array}$ & 50 & $5 \cdot 3$ & & 0.76 & \\
\hline & $\begin{array}{l}\text { UC-Nawaan } \\
\text { Kalay }\end{array}$ & 50 & 5.4 & & 0.78 & \\
\hline
\end{tabular}

Survey Results: 2010

The average household size is 5.4 as shown in table 1 . This value is the average household size of all three selected district. It explained that in the study area the families are like to live jointly and more than 6 people 


\section{Review of Economics and Development Studies, Vol. 6 (4) 2020881 - 891}

reside in a household. The results indicate that the average household size for Kaanju is 5.5, Charbagh 5.3 and for Nawaan Kalay is 5.4. The study concluded that it's difficult to enroll all of the children in schools due to the larger family size. The variable dependency ration has a significant role in the study and it reflects the mind of household's behavior while to spending on education and health. In the last few years the importance of the dependency ration has been followed very keenly. The household size defines as; less than age $15+$ above 64 years divides by aged 15-64 years. The average dependency ratio is given as respectively 0.74 in Kaanju, 0.76 in Charbagh Cham and 0.78 in Nawaan Kalay. This is may be a reason very few of the children getting access to schools in study area.

\subsection{Educational profile of the respondents}

According to the census of 1998 the literacy rate in Swat is $41.79 \%$. The male are comparatively highly literate than female, male literacy rate is $55.97 \%$ and female is $25.5 \%$. The profile of education of the respondent is elaborated in below table:

Table 2

Education Status of the respondents

\begin{tabular}{|c|c|c|c|c|c|c|}
\hline Education & UC-Kaanju & $(\%)$ & $\begin{array}{l}\text { UC-Charbagh } \\
\text { Cham }\end{array}$ & $(\%)$ & $\begin{array}{l}\text { UC- } \\
\text { Nawaan } \\
\text { Kalay }\end{array}$ & $(\%)$ \\
\hline Illiterate & 8 & 16 & 9 & 18 & 15 & 30 \\
\hline Primary & 12 & 24 & 9 & 18 & 14 & 28 \\
\hline SSC & 25 & 50 & 25 & 50 & 13 & 26 \\
\hline HSSC & 4 & 8 & 5 & 10 & 4 & 8 \\
\hline Graduate & $\mathrm{O}$ & $\mathrm{O}$ & 2 & 8 & 2 & 4 \\
\hline Master & 1 & 2 & $\mathrm{O}$ & $\mathrm{O}$ & 2 & 4 \\
\hline Total & 50 & 100 & 50 & 100 & 50 & 100 \\
\hline
\end{tabular}

The above table revealing the respondents they have different level of qualifications. According to the result 24 out of the total have high school degrees and this fall in the percentage of $50 \%$. In Charbagh Cham majority have qualified matriculation but in Nawaan Kalay most of the respondents even did not attend the school and are illiterate.

\subsection{Consumption patterns of the respondent}

The consumption patterns shows the overall spending of household on consumption goods, such as; clothing, food, rent and transportation etc. the following table reveals the consumption behavior of the respondents on various items in the study area.

Table 3: Expenditure items (as \% of income)

\begin{tabular}{|l|l|l|l|l|}
\hline Area & UC-Kaanju & $\begin{array}{l}\text { UC-Charbagh } \\
\text { Cham }\end{array}$ & $\begin{array}{l}\text { UC-Nawaan } \\
\text { Kalay }\end{array}$ & Overall (\%) \\
\hline Foods & 55 & 52 & 49 & 49 \\
\hline Education & 9 & 9 & 6 & 7.56 \\
\hline Health & 5 & 7 & 13 & 8 \\
\hline Accomudation & 0 & 3 & 0 & 0.76 \\
\hline Repair\&maintenance & 3 & 1 & 3 & 2.56 \\
\hline Utility charges & 8 & 11 & 10 & 12 \\
\hline Cloth \& foot wear & 17 & 9 & 12 & 11.66 \\
\hline Transportation & 7 & 10 & 7 & 8.23 \\
\hline Total & 100 & 100 & 100 & 100 \\
\hline
\end{tabular}

The results in table 3 indicate that in union council Kaanju the majority of the respondents spent a large 
Review of Economics and Development Studies, Vol. 6 (4) 2020881 - 891

part of their income on education, health and food which is $64 \%$. In the remaining two union councils the respondent also spent a major part of income on education, health and food, which is $61 \%$ and same for the two union councils. The remaining part of income spent on some other necessary items such as clothing, footwear, transportation and utility bills.

\subsection{Type of School Systems for the children in the sampled areas}

In the region there are two types of educational institutions, especially our interest is school. The government schools and private schools. The fee structure in government schools is affordable but the education provided by the government schools is not have quality. In other hand the private school they take high fees and facilitate the student efficiently. The following table indicates the type of the schools systems and children in all the sample areas are attending the schools.

Table 4: Type of the schools and enrollment is the sample area

\begin{tabular}{|l|l|l|l|l|l|l|}
\hline Education & $\begin{array}{l}\text { UC- } \\
\text { Kaanju }\end{array}$ & \%age & $\begin{array}{l}\text { UC-Charbagh } \\
\text { Cham }\end{array}$ & \%age & $\begin{array}{l}\text { UC- } \\
\text { Nawaan } \\
\text { Kalay }\end{array}$ & \%age \\
\hline Public School & 36 & 69 & 40 & 80 & 36 & 72 \\
\hline Private School & 14 & 31 & 10 & 20 & 14 & 28 \\
\hline Total & 50 & 100.0 & 50 & 100 & 50 & 100 \\
\hline
\end{tabular}

The results revealed the majority of the respondents (69\%) preferred to send their children to government schools. It can be a reason that the low income level of the household compelled them to send their children to the government school. The table also reveals that only $31 \%$ student access to the private schools, the tendency of enrollment towards private school is comparatively low, it is due different of reasons, e.g. the private schools charge high fee and it may have security risk.

\subsection{Satisfaction with Government Actions}

Its regularly known from the respondents regarding the government policies whether they were satisfied from the policy measures. The objectivity of the question is to knowing about the opinion of respondent's on policy measures of the government. The opinions of the respondents are taken, whether they are satisfied from the government necessary measures or not. In the following table the comments of the respondents are shown.

Table 5: Satisfaction from government actions in education \& health

\begin{tabular}{|l|l|l|l|l|l|l|}
\hline Education & UC-Kaanju & \%age & $\begin{array}{l}\text { UC-Charbagh } \\
\text { Cham }\end{array}$ & \%age & $\begin{array}{l}\text { UC-Nawaan } \\
\text { Kalay }\end{array}$ & \%age \\
\hline No & 42 & 84 & 40 & 80 & 44 & 88 \\
\hline Yes & 8 & 16 & 10 & 20 & 6 & 12 \\
\hline Total & 50 & 100 & 50 & 100 & 50 & 100 \\
\hline
\end{tabular}

The above table expresses the government steps for betterment of education and health system. The results conclude that in Kaanju district $80 \%$ respondents opinioned that they do not satisfy from the government's measures. The majority of the respondents are also not satisfied by the government's dealing of the two remaining district Charbagh Cham and Nawaan Kalay, respectively $84 \%$ and $80 \%$ not satisfied. Especially the rural areas in selected district the people are using the government's goods and getting education from the government's schools and access to government hospital, the respondents think that the provision of all that commodities and goods do not have qualities to satisfy. 


\subsection{Expected returns from human capital investment}

In the following table 6.14 shows the household behavior and response regarding the expected return spending on human capital.

Table 6

Expected Returns from Human Capital Investment

\begin{tabular}{|l|l|l|l|l|l|l|}
\hline Education & $\begin{array}{l}\text { UC- } \\
\text { Kaanju }\end{array}$ & \%age & $\begin{array}{l}\text { UC-Charbagh } \\
\text { Cham }\end{array}$ & \%age & $\begin{array}{l}\text { UC- } \\
\text { Nawaan } \\
\text { Kalay }\end{array}$ & \%age \\
\hline $\begin{array}{l}\text { Highly dis- } \\
\text { satisfied }\end{array}$ & 5 & 10 & 3 & 6 & 2 & 4 \\
\hline Dis-satisfied & 1 & 2 & 12 & 24 & 2 & 4 \\
\hline $\begin{array}{l}\text { Neither } \\
\text { satisfied nor } \\
\text { dis-satisfied }\end{array}$ & 5 & 10 & 4 & 8 & 4 & 8 \\
\hline Satisfied & 14 & 28 & 17 & 34 & 20 & 40 \\
\hline Highly-satisfied & 25 & 50 & 14 & 28 & 22 & 44 \\
\hline Total & 50 & 100 & 50 & 100 & 50 & 100 \\
\hline
\end{tabular}

Table 6.14 indicates the in Kaanju district large sizes of the respondents (80\%) love to spend more on education and health and expecting greater return in future. Accordingly the expectations of the respondents, when the children will be academically trained and mentally healthy they inducted in high position and earn more.

\subsection{Prices of goods and services}

The following table indicates the price of goods and services of the respondents they responded during the survey.

Table 7

Prices of goods and services related to investment in human capital

\begin{tabular}{|l|l|l|l|l|l|l|}
\hline Education & $\begin{array}{l}\text { UC- } \\
\text { Kaanju }\end{array}$ & \%age & $\begin{array}{l}\text { UC-Charbagh } \\
\text { Cham }\end{array}$ & \%age & $\begin{array}{l}\text { UC- } \\
\text { Nawaan } \\
\text { Kalay }\end{array}$ & \%age \\
\hline $\begin{array}{l}\text { Highly dis- } \\
\text { satisfied }\end{array}$ & 11 & 22 & 12 & 24 & 10 & 20 \\
\hline Dis-satisfied & 22 & 44 & 20 & 40 & 23 & 46 \\
\hline $\begin{array}{l}\text { Neither } \\
\text { satisfied nor } \\
\text { dis-satisfied }\end{array}$ & 7 & 14 & 8 & 16 & 8 & 16 \\
\hline Satisfied & 9 & 18 & 6 & 12 & 7 & 14 \\
\hline $\begin{array}{l}\text { Highly- } \\
\text { satisfied }\end{array}$ & 1 & 2 & 4 & 8 & 2 & 4 \\
\hline Total & 50 & 100 & 50 & 100 & 50 & 100 \\
\hline
\end{tabular}

This table reveals the prices of those goods and services relating to spending on human capital including education and health in the sleeted district, district Kaanju, Charbagh Cham and Nawaan Kalay and the respondents exceptionally gave positive responses respectively $63 \%, 64 \%$ and $66 \%$. Accordingly the results in above table the people move their children towards private schools and hospital in spite of charging high fees. As already discussed, majority of the sampled households cannot afford to educate their kids in standard education and health institutions due to high fees, which they are unable to pay. 
Review of Economics and Development Studies, Vol. 6 (4) 2020881 - 891

In the following table the regression's results are given and it has employed each of the area separately. The variation in household behavior relating to spending on human resources is observed while to undertake some of the important variables. The results of the estimated model are given as follows;

Table 8: Results of the factors affecting HCI

\begin{tabular}{|c|c|c|c|c|}
\hline Variables & Kaanju & $\begin{array}{l}\text { Charbagh } \\
\text { Cham }\end{array}$ & Nawan kaly & Overall \\
\hline Const & 0.712 & 0.954 & -5.620 & 4.670 \\
\hline Family-Income & $\begin{array}{l}0.286 \\
(3.323)^{*}\end{array}$ & $\begin{array}{l}0.518 \\
(7 \cdot 319)^{*}\end{array}$ & $\begin{array}{l}0.329 \\
(3.117)^{*}\end{array}$ & $\begin{array}{l}0.654 \\
(7.491)^{* *}\end{array}$ \\
\hline Family-Education & $\begin{array}{l}0.922 \\
(7.844)^{\text {** }}\end{array}$ & $\begin{array}{l}0.611 \\
(2.776)^{*}\end{array}$ & $\begin{array}{l}0.563 \\
(8.862)^{*}\end{array}$ & $\begin{array}{l}0.380 \\
(5.330)^{*}\end{array}$ \\
\hline $\begin{array}{ll}\text { Price } & \text { of } \\
\text { goods\&services }\end{array}$ & $\begin{array}{l}-0.582 \\
(-3.219)^{*}\end{array}$ & $\begin{array}{l}-0.612 \\
(-14.320)^{*}\end{array}$ & $\begin{array}{l}-0.486 \\
(-8.431)^{*}\end{array}$ & $\begin{array}{l}-0.589 \\
(-12.138)^{* * *}\end{array}$ \\
\hline $\begin{array}{ll}\text { Quality } & \text { of } \\
\text { goods\&services }\end{array}$ & $\begin{array}{l}0.023 \\
(3.714)^{*}\end{array}$ & $\begin{array}{l}-0.670 \\
(-1.651)\end{array}$ & $\begin{array}{l}0.072 \\
(4.973)^{*}\end{array}$ & $\begin{array}{l}0.350 \\
(1.236)\end{array}$ \\
\hline $\begin{array}{ll}\text { Availability } & \text { of } \\
\text { goods\&services }\end{array}$ & $\begin{array}{l}1.169 \\
(2.496)^{*}\end{array}$ & $\begin{array}{l}0.340 \\
(7.858)^{*}\end{array}$ & $\begin{array}{l}0.344 \\
(2.831)^{*}\end{array}$ & $\begin{array}{l}0.458 \\
(6.463)^{*}\end{array}$ \\
\hline Expected Return & $\begin{array}{l}0.017 \\
(1.019) \\
\end{array}$ & $\begin{array}{l}0.547 \\
(7.846)^{*}\end{array}$ & $\begin{array}{l}0.360 \\
(1.340)\end{array}$ & $\begin{array}{l}0.048 \\
(1.049)\end{array}$ \\
\hline Religion & $\begin{array}{l}-0.470 \\
(-4.402)^{*}\end{array}$ & $\begin{array}{l}-0.113 \\
(-2.526)^{* *}\end{array}$ & $\begin{array}{l}-0.012 \\
(-0.743)\end{array}$ & $\begin{array}{l}-0.233 \\
(-6.240)^{*}\end{array}$ \\
\hline Family-Structure & $\begin{array}{l}0.157 \\
(2.145)^{* *}\end{array}$ & $\begin{array}{l}0.020 \\
(0.842) \\
\end{array}$ & $\begin{array}{l}0.169 \\
(2.810)^{* * *}\end{array}$ & $\begin{array}{l}0.231 \\
(2.833)^{* *}\end{array}$ \\
\hline $\mathrm{D}_{\mathrm{t}}$ & $\begin{array}{l}-0.067 \\
(-2.31)^{* *}\end{array}$ & $\begin{array}{l}-0.117 \\
(-2.92)^{* *}\end{array}$ & $\begin{array}{l}-0.122 \\
(-2.783)^{* * *}\end{array}$ & $\begin{array}{l}-0.603 \\
(-5.264)^{*}\end{array}$ \\
\hline $\mathrm{D}_{\mathrm{fs}}$ & $\begin{array}{l}0.134 \\
(1.31)\end{array}$ & $\begin{array}{l}0.056 \\
(1.92)^{* * *}\end{array}$ & $\begin{array}{l}0.041 \\
(0.783)\end{array}$ & $\begin{array}{l}0.603 \\
(2.264)^{* *}\end{array}$ \\
\hline $\mathrm{D}_{\mathrm{r}}$ & $\begin{array}{l}-0.431 \\
(-4.13)^{*}\end{array}$ & $\begin{array}{l}-0.237 \\
(-2.34)^{* *}\end{array}$ & $\begin{array}{l}-0.412 \\
(-1.983)^{* * *}\end{array}$ & $\begin{array}{l}-0.448 \\
(-4.210)^{*}\end{array}$ \\
\hline $\mathrm{R}^{2}$ & 0.986 & 0.968 & 0.993 & 0.973 \\
\hline $\mathrm{F}$ & 521.358 & 524.522 & 661.334 & 429.630 \\
\hline D.W & 2.1 & 1.9 & 1.9 & 2.2 \\
\hline
\end{tabular}

The regression result in above table revealed for each of the union council in the study area. The association between household income and household expenditure on health and education is positive and significant. The study further shows that the relationship between family education and household behavior is positive. It is justified as; the educated families take more sophisticated measures for the education and health of their children. It also revealed that the price of goods concerning education and health inversely effect the spending on human resources in all the union council of the behavior of household. The expenditure on household behavior is inversely affected by the quality of goods and services in union council Charbagh. Similarly the spending on household behavior negatively influence by those goods and services which are easily available and the result is statistically significant. The results concluded that the expected return on spending on human capital has direct and significant 
Review of Economics and Development Studies, Vol. 6 (4) 2020881 - 891

effect on the investment's behavior in Charbagh Cham union council and the remaining two districts the impact has also positive but statistically insignificant. The study resulted in all selected district the religious status impact on the human capital investment behavior. It justified as the inhabitants are religious loving people and they do not spend more of their income on education and health. The capital investment effected by family structure directly and it shows significant impact only Charbagh Cham union council. The results explore that the joint and nuclear families both spend not a major part of their income on education and health. The terrorism has used as dummy variable in the model and it has inverse effect on investment behavior. In the study area due fear of terrorist attack the people do not willing to invest on education and health and all the education institution were badly suffer. The study concluded that the terrorism severely discouraged the human capital development.

The table below uses VIF to check multicollinearity

Table 9: Collinearity diagnostics

\begin{tabular}{|l|l|l|l|}
\hline \multirow{2}{*}{ Model } & \multicolumn{2}{l|}{ Collinearity Statistics } \\
\cline { 3 - 4 } & & Tolerance & VIF \\
\hline \multirow{5}{*}{1} & (Constant) & & \\
\cline { 2 - 4 } & Income & .951 & 1.051 \\
\cline { 2 - 4 } & Family Background & .905 & 1.105 \\
\cline { 2 - 4 } & Prices goods\&services & .892 & 1.121 \\
\cline { 2 - 4 } & Quality of goods\&services & .911 & 1.098 \\
\cline { 2 - 4 } & Availability of goods\&services & .842 & 1.187 \\
\cline { 2 - 4 } & Expected Returns & .978 & 1.023 \\
\cline { 2 - 4 } & Religion & .624 & 1.603 \\
\cline { 2 - 4 } & Family Structure & .683 & 1.464 \\
\cline { 2 - 4 } & $D_{\mathrm{t}}$ & .937 & 1.067 \\
\hline
\end{tabular}

The table shows that VIF values are less than 5 , so there is no problem of multicollinearity.

\section{Conclusions}

Human development investment is playing a leading role to development of any society. Most of the countries preferably spend on human resources for economic growth. The study has undertaken investment behavior of households to exploit the human resources development. The results found that the education level, health facilities, family structure, availability, quality and expected return have positive association with behavior of household spending. The study also found indirect relationship between religious status, terrorism and human capital spending. The study made some recommendations that the government should take necessary measures towards education, health and food nutrition. The effected policies should be enacted that provide awareness relating health and education. It is also suggested that basic free health and education facilitations should be provided. Finally it is recommended that the top priority of the government should be to spend the major part of national income for human resource development.

\section{References}

Abbas, Q. (2000) The Role of Human Capital in Economic Growth: A Comparative Study of Pakistan and India, The Pakistan Development Review 39:4, 451-473.

Fredickson, B. (1991) An Analysis of the Student Enrollment and flow Statistics. Population and Human Resource Department, The World Bank, Washington D.C 
Review of Economics and Development Studies, Vol. 6 (4) 2020881 - 891

Government of Pakistan (2003) Investing in Human Capital. Poverty Reduction Strategy Paper, 66-95.

Jere R. B. (1987) Human Resource Led Development. New Delhi, India: ARTEP/ILO.

Jere R. B. (1990) Investing in Female Education for Development: Women in Development Strategy for 1990s in Asia and the near East. Williamstown: Williams College.

Jere R. B., \& Schneider, R. (1993) An International Perspective on Pakistani Human Capital Investments in the last Quarter Century, The Pakistan Development Review 32:1, 1-68.

Jere R, B., \& Anil, B. D. (1998) Health and Nutrition. Hand Book On Economic Development, Vol. 1 Amsterdam: North Holland Publishing Co. 631-711.

Khan, A. (2018). How does terrorism measurement matter of state-level of a country? Evidence from Islamic countries. Qual Quant. 52:883-898.

Khan, A., Ruiz-Estrada, M. A., \& Yusof, Z. (2016): How Terrorism Affects the Economic Performance: The Case of Pakistan. Qual Quant, 50(2), pp 867-883

Khan, F (2019) Exploring the effect of terrorism on education sector: A case of Khyber Pakhtunkhwa, City University Research Journal, Vol. 19, Issue 2, 51-68.

Lawrence, H. S. (1992) Investing in All the People. The Pakistan Development Review 31:4, 367404 .

Mimoun, B., Mohamed., R., \& Asma (2008): Human capital investment and growth: A dynamic education model. Journal of Business Affairs 2(1), pp 1-22.

Nelson, R.R. and Phelps, E. S. (1966) Investment in Humans, Technological Diffusion, and Economic Growth. American Economic Review, 56, 69-75.

Neilson, E. (2020) "Essays on the Determinants of Human Capital Investment". All Dissertations. 2627. https://tigerprints.clemson.edu/all_dissertations/2627

Romer, P. M. (1986) Increasing Returns and Long Run Growth. Journal of Political Economy 94, 1002-1037

Rosen, S. (1976) A Theory of Life Learning. Journal of Political Economy 84, PP 545-567

Ruiz-Estrada, M. A., Park, D., Kim, J. S., \& Khan, A. (2015). The Economic Impact of Terrorism: A New Model and Its Application to Pakistan. Journal of Policy Modeling, pp 204-214

Siddiqui, R, Afridi, U., \& Haq, R. (1995) Determinants of Expenditure on Health in Pakistan. The Pakistan Development Review 31:4,PP 959-970

Schultz, W. T. (1961) Investment in Human Capital. American Economic Review 51, 1-17

Shahid, H. A. (2003) Economic Planning of Pakistan, Ilmi Kitab Khana, Urdu Bazar Lahore. 255296.

Summers, H. Lawrence (1992) Investing in All the People. The Pakistan Development Review 31:4, 367-404.

Uzama, H. (1965) Optimal Technical Change in an Aggregate Model of Economic Growth. International Economic Review 6, 18-31.

UNESCO (1990) Annual Yearbook, Paris: UNESCO

World Bank Development Report, 2003, Washington: World Bank

Yamauchi, F. et al (2009) Natural disasters, self-insurance, and human capital investment: evidence from Bangladesh, Ethiopia, and Malawi, IFPRI Discussion paper oo881.

Yang, C.-H., Lin, C.-H. and Ma, D. (2010), R\&D, Human Capital Investment and Productivity: Firm-level Evidence from China's Electronics Industry. China \& World Economy, 18: 72-89. 